\title{
ガラス研磨用エポキシ樹脂研磨パッドの開発*
}

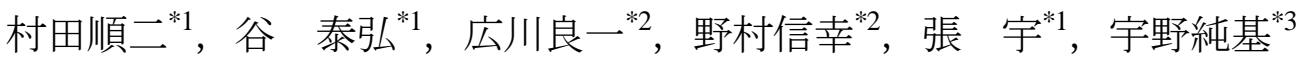

\section{Development of Epoxy Resin Polishing Pads for Glass Polishing}

\author{
Junji MURATA*1, Yasuhiro TANI, Ryoichi HIROKAWA, Nobuyuki NOMURA, \\ Yu ZHANG and Junki UNO \\ ${ }^{* 1}$ Ritsumeikan Univ., Dept. of Mechanical Engineering \\ 1-1-1 Noji-Higashi, Kusatsu, Shiga, 525-8577 Japan
}

This paper describes newly developed polishing pads for glass finishing that employs an epoxy resin instead of a conventional polyurethane resin. The porosity of the polishing pad was controlled by changing the amount of a chemical foaming agents mixed with a prepolymer epoxy resin. It was found that the removal rate of glass surface using epoxy polishing pad was approximately two times higher than those using urethane polishing pad, which means a 50 percent decrease in a usage of $\mathrm{CeO}_{2}$ abrasives. The waviness and edge roll-off of polished glass surfaces were markedly improved by utilizing epoxy polishing pads, while the surface roughness of glass surfaces finished by epoxy pads was comparable to that finished by urethane pads. The investigation of substitute abrasive materials exhibited that the $\mathrm{CeO}_{2}$ abrasives were completely substituted for $\mathrm{ZrO}_{2}$ abrasives. The mechanism of higher removal rate of epoxy polishing pads was also investigated using measurement of contact angles, sliding angles and dynamic friction coefficient of polishing pads. These measurements indicate that abrasive grains are supported more strongly on the epoxy polishing pad than on the urethane polishing pad, namely, higher relative velocity between workpiece surface and abrasive grains to be obtained.

Key Words : Ultra-Precision Machining, Polishing, Tool, Abrasive Grain, Polishing Pad, Epoxy Resin, Glass

\section{1. 緒言}

液晶テレビ用フラットパネルディスプレイ基板や磁気ディスク基板，レンズやプリズムなどの各種光学素子な どのガラス製品は所定の形状に加工された後，最終的には研磨によって表面が平滑化される．ガラスの鏡面研磨 には，高い研磨能率が得られることや高品位仕上げが可能であることから，従来から酸化セリウム $\left(\mathrm{CeO}_{2}\right)$ 砥粒 が広く用いられている，その金属元素であるセリウムは，希土類金属（レアアース）の一つであり，中国が 97\% 以上の供給量を占めている，昨今のレアアースの輸出制限を受け，酸化セリウム砥粒の供給が不足しており，国 内における価格が急騰しているのが現状である. このような背景のもと，ガラスの精密研磨における酸化セリウ ムの使用量を低減する技術や，他の砥粒に代替する技術の開発が急務となっている，そこで，高機能研磨パッド の開発の一つとして，従来のウレタン樹脂パッドに代わる材料としてエポキシ樹脂を採用した研磨パッドの開発 を行っている(1). エポキシ樹脂は接着剤や半導体の封止剤として広く用いられている(2)他，レジンボンド砥石の結 合剂 ${ }^{(3)}$ として用いられている。しかし，エポキシ樹脂を用いた研磨パッドの報告例は少なく(4)，また，実用的な製 品が開発されていないのが現状である. 本論文では，熱硬化によりガラスの研磨に適したエポキシ樹脂研磨パッ ドを開発し，その研磨特性の評価を行うとともに，従来のウレタンパッドとの性能比較を行った。また，エポキ シ研磨パッドを用いることにより, 酸化セリウムを代替する砥粒の可能性について検討を行った. さらに，エポ

* 原稿受付 2011 年 1 月 6 日

*1 正員, 立命館大学理工学部機械工学科（广525-8577 滋賀県草津市野路東 1-1-1）

*2 九重電気 (株) （广259-1146 神奈川県伊勢原市鈴川 16）

*3 立命館大学理工学部機械工学科（T525-8577 滋賀県草津市野路東 1-1-1）

E-mail: murata06@fc.ritsumei.ac.jp 
Table1 Properties of urethane and epoxy polishing pads

\begin{tabular}{|c|c|c|c|c|}
\hline \multicolumn{2}{|c|}{} & Urethane & Low-foamed epoxy & High-foamed epoxy \\
\hline \multirow{2}{*}{$\begin{array}{c}\text { mixing } \\
\text { ratio }\end{array}$} & Resin & - & 100 & 100 \\
\cline { 2 - 5 } & Curing agent & - & 55 & 55 \\
\cline { 2 - 5 } & Foaming agent & - & 2 & 5 \\
\hline \multicolumn{2}{|c|}{ Density $\left(\mathrm{g} / \mathrm{cm}^{3}\right)$} & 0.40 & 0.63 & 0.40 \\
\hline \multicolumn{2}{|c|}{ Hardness (JIS-A) } & 78 & 97 & 90 \\
\hline \multicolumn{2}{|c|}{ Tensile strength (MPa) } \\
\multicolumn{2}{|c|}{ Young's modulus (MPa) } & 3.9 & 4.9 & 1.9 \\
\hline
\end{tabular}

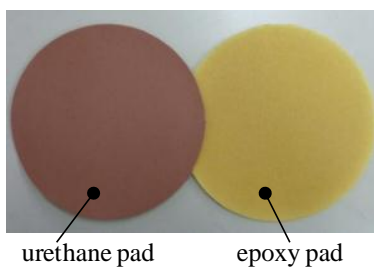

Fig. 1 Appearance of polishing pads $(\phi 200 \mathrm{~mm})$
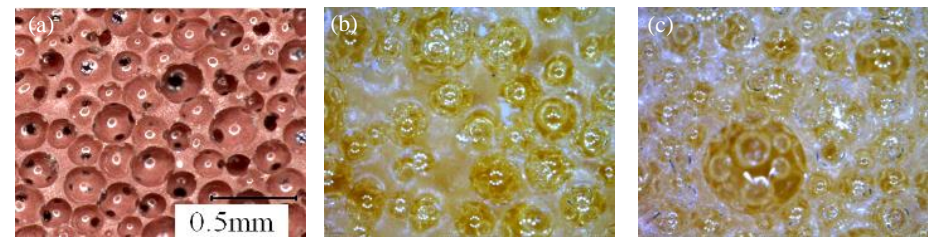

Fig. 2 Optical microscope images of polishing pad surfaces. (a) urethane pad, (b) low-foamed epoxy pad, and (c) high-foamed epoxy pad .

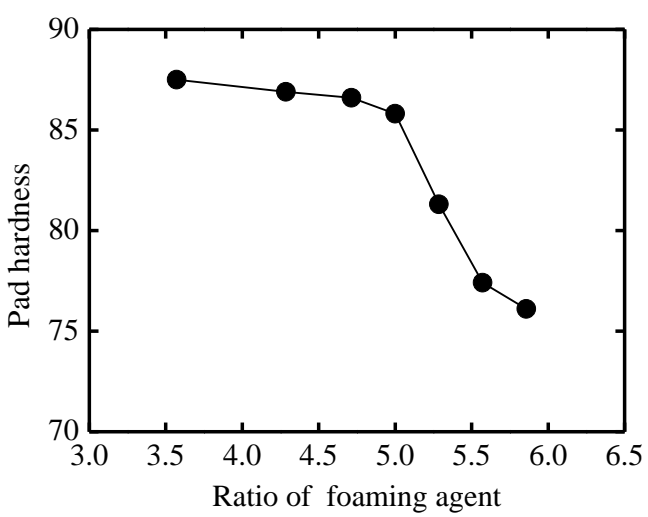

Fig. 3 Relationship between pad hardness and ratio of foaming agent

キシ樹脂研磨パッドを用いた際に，高い研磨特性が得られる原因について，研磨パッドの材料物性の観点から考 察を行ったので報告する.

\section{2. エポキシ樹脂研磨パッドの作製}

熱硬化によりエポキシ樹脂研磨パッド（以下，エポキシパッドとする）の作製を行った．エポキシ樹脂のプレ ポリマ，硬化剤および気孔を形成するための発泡剂等を混合しそれを金型に注型した後，所定の温度に加熱し， 発泡および硬化を行う。硬化した樹脂を金型より離型し，一定の厚さにスライスを行った後，用いる研磨機に合 わせた形状に切断を行う。本研究では, 樹脂に配合する発泡剂の添加量を変更した複数のエポキシパッドを作製 した．表 1 に代表的なエポキシパッドの樹脂配合量を示寸. エポキシ樹脂のプレポリマ 100 に対して，硬化剤を 55 の割合で配合した，研磨パッドの発泡率（密度）を変化させるため，発泡剂の割合を変化させた．図 1 に作製 した直径 200mm の大きさのエポキシパッドおよび市販のセリア含有発泡ポリウレタン研磨パッド (九重電気(森) 製, KSP-66A, 以下ウレタンパッドとする.）の外観写真を示す. 表 1 の研磨パッドの機械的物性值に示すように, 発泡剂の添加量を変えることで, 研磨パッドの気孔率（密度）の調整が可能であり, それに伴い硬度や引張強度 などの物性值が異なっていることがわかる，ウレタンパッドと比較して，同じ密度でもエポキシパッドの方がや や硬度が高いが，引張強度は低くなっている．それぞれの研磨パッドを光学顕微鏡により観察したものが図 2 で ある. 発泡剂を添加することにより，研磨パッド内部および表面に気孔が形成されていることがわかる（図 $2(b$, c)）. 気孔径は数百 $\mu \mathrm{m}$ のオーダであり, ウレタンパッド (図 2 (a) ) と同程度のものが得られた. また, 発泡剂 の量を変化させることで，気孔率が異なってくることが確認された．図 3 に樹脂量 100 に対寸る発泡剂添加率と 硬化後のエポキシパッドの硬度の関係を示す. 発泡剂添加量の増加に伴い, 研磨パッド内の気孔率が増加するた め，結果としてエポキシパッドの硬度が低下寸る傾向にあることがわかった. 
Table 2 Polishing condition

\begin{tabular}{|l|l|}
\hline Polishing machine & $\begin{array}{l}\text { Lapping machine NF-300 } \\
\text { Nano Factor Co.,Ltd }\end{array}$ \\
\hline Workpiece & $\begin{array}{l}\text { Sodalime glass: } \phi 20 \mathrm{~mm} \times 10 \mathrm{~mm} \\
\text { Surface roughness: } R \mathrm{a} 0.4 \mu \mathrm{m}\end{array}$ \\
\hline Pressure & $20 \mathrm{kPa}$ \\
\hline Work/Lap rotation & $90 \mathrm{rpm} / 90 \mathrm{rpm}$ \\
\hline Polishing time & $30 \mathrm{~min}$ \\
\hline abrasives & $\begin{array}{l}1.2 \mu \mathrm{m} \mathrm{CeO} \text { (SHOROX A-10 } \\
\text { Showa Denko K.K.) }\end{array}$ \\
\hline Concentration of slurry & $3.0 \mathrm{wt} \%$ in deionized water \\
\hline Supply rate of slurry & $25 \mathrm{~mL} / \mathrm{min}$ \\
\hline
\end{tabular}

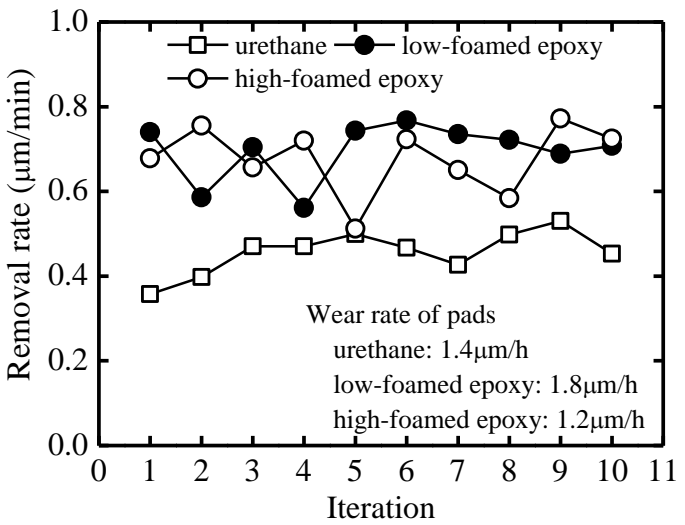

Fig. 5 Transition of removal rate as a function of iteration count

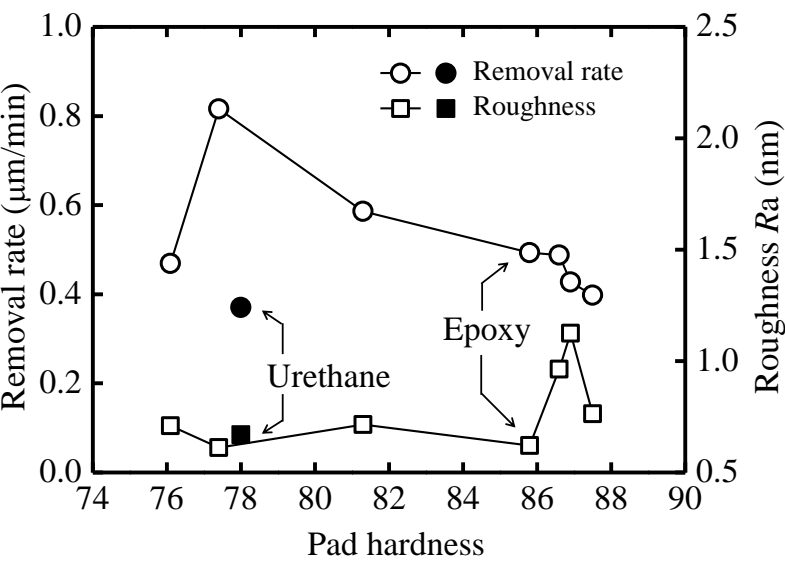

Fig. 4 Polishing performance as a function of pad hadness
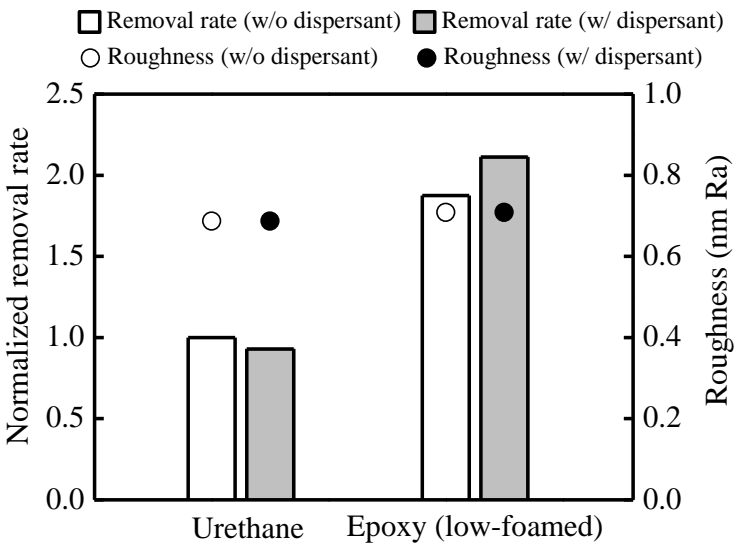

Fig. 6 Effect of the dispersant on polishing performance

\section{3. ガラスの研磨特性の評価}

作製したエポキシパッドによりガラスの研磨実験を行い，その研磨特性の評価を行った．表 2 に研磨実験条件 を示す．研磨機には，定盤径 200mm の片面精密ラッピング装置（侏ナノファクタ製，NF-300）を用いた．工作 物にはソーダガラスを用い，3 点の工作物を直径 $90 \mathrm{~mm}$ のワークホルダに対し，中心から半径 $35 \mathrm{~mm}$ の位置に等 間隔で貼付けた．工作物表面は，前処理として\#1200の緑色炭化珪素（GC）砥粒を用いたラッピングにより表面 粗さ $R \mathrm{a}$ を約 $0.4 \mu \mathrm{m}$ に加工した. 研磨パッドの表面は, 研磨機上において刃先曲率半径 $1 \mathrm{~mm}$ のバイトを用いて, 切込み量 $150 \mu \mathrm{m}$ ，バイト送り速度 $0.5 \mathrm{~mm} / \mathrm{s}$ ，パッド回転速度 $100 \mathrm{rpm}$ の条件で切削（フェイシング）を行った．そ の後，\#100 のダイヤモンド電着ドレッサを用いて，ドレッサパッド回転速度 $90 \mathrm{rpm}$ の条件でドレッシングを 10 分間行った．研磨能率は加工前後の工作物の質量差によって算出した． 研磨後工作物の表面粗さは，白色式位相 シフト干渉顕微鏡（Zygo, Newview 5032）を用いて，カットオフ值 $0.08 \mathrm{~mm}$ の高域フィルタを適用して評価した.

\section{$3 \cdot 1$ 研磨能率の評価}

図 4 に作製したエポキシパッドの研磨能率および研磨後工作物表面粗さとパッド硬度の関係を示す. 開発した エポキシパッドはおおむ称ウレタンパッドと比較して高い研磨能率が得られており, パッド硬度が小さくなると 共に研磨能率が増加することがわかる．特に，ウレタンパッドと同程度の硬度（78）を持つエポキシパッドの研 磨能率が最も高く，市販ウレタンパッドと比較して 2 倍強の能率が得られた。一般に研磨パッドの硬度が高くな ると工作物への当たりが悪くなり研磨能率が減少する．本研究では，一般的に高硬度なエポキシ樹脂を市販ウレ タンパッドと同程度まで硬度を低下させた結果，エポキシ樹脂の持つ性質を発現でき高い研磨能率が得られたと

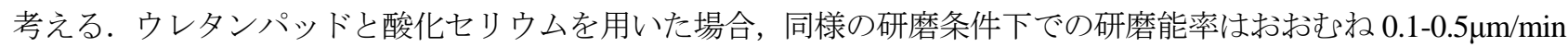
であることが報告されており ${ }^{(5)}$ ，これらの值と比較してもエポキシパッドが高い研磨能率を持つことがわかる. 


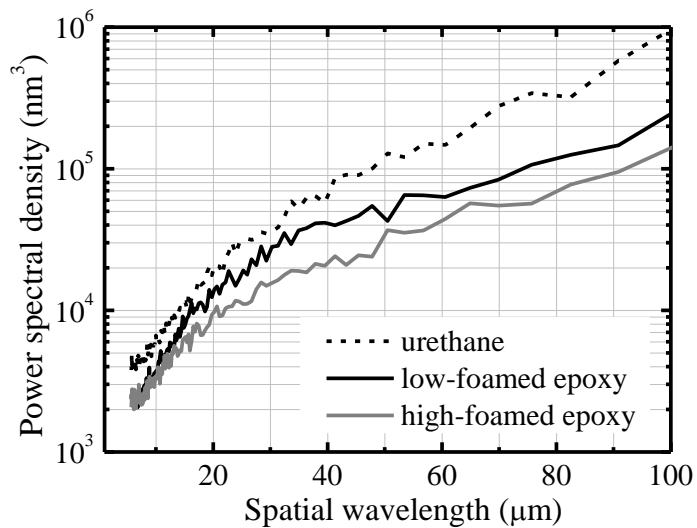

Fig. 7 Power spectral density profiles of polished glass surfaces.

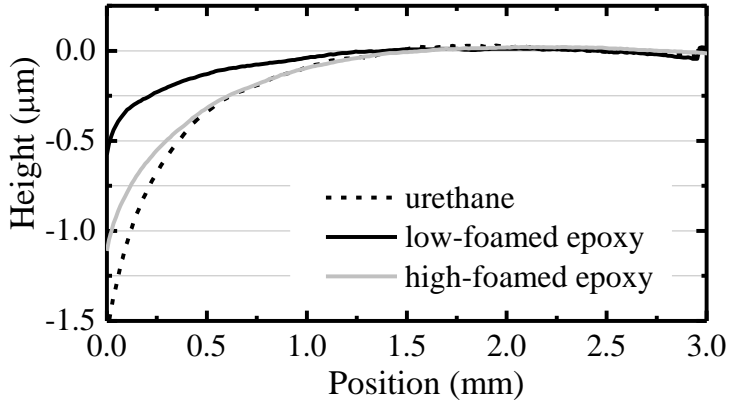

Fig. 9 Cross-sectional profiles of polished glass edges.
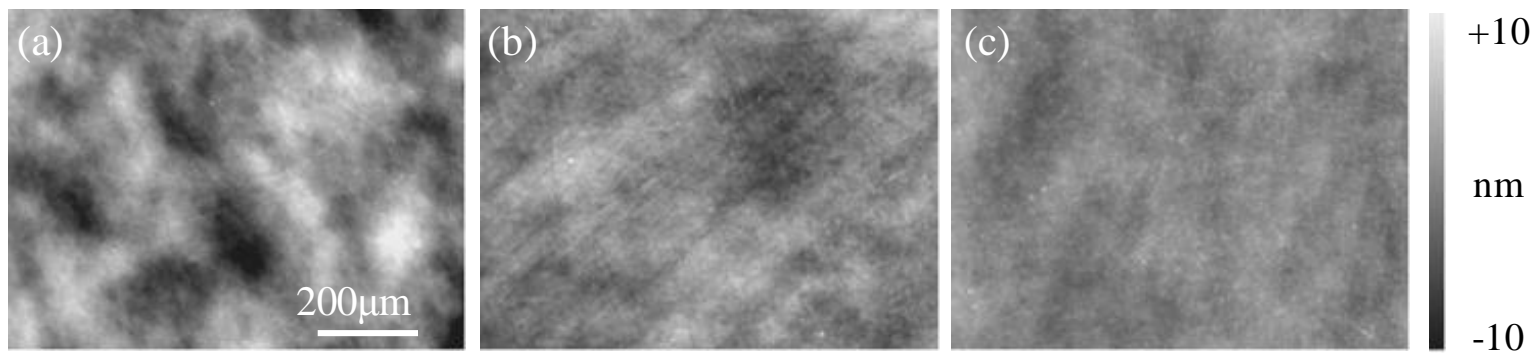

Fig. 8 Optical interferometer images of glass surfaces polished using (a) urethane pad (Wa:3.841nm), (b) low-foamed epoxy pad (Wa: $1.645 \mathrm{~nm}$ ), and (c) high-foamed epoxy pad (Wa:0.985nm).

詳細については後述するが，ウレタンパッドよりも高い研磨能率が得られた要因としては，エポキシパッドのセ ルフドレス性が高いことやパッド表面のスラリーに対する親和性が高く，砥粒の保持力が高いことなどが考えら れる. エポキシパッドの硬度を 78 以下にすると, 高い気孔率のためパッド表面の摩耗が激しく, 研磨能率が低下 した. ウレタンパッドに対し，2 倍の研磨能率が得られたことは，同一量を研磨するのに必要な時間が半減した ことを意味する，スラリーの供給量は同一であるため，結果として $50 \% の$ 酸化セリウム使用量の低減を実現した ことになる.

次に各研磨パッドの研磨能率の経時変化を評価した。一般的に研磨パッドは一定時間研磨を行うと研磨能率が 徐々に低下するため，所定時間経過後にドレッシングを実施する．本実験では， 1 回目の研磨実験前にのみドレ ッシングを行い, 30 分間の研磨実験を同条件で繰り返し実施した. 各研磨実験毎のドレッシングは行っていない. 図 5 に各研磨パッドの研磨能率と実験回数の関係を示寸．エポキシパッドは，各実験毎のバラツキが認められる が，平均的にはウレタンパッド以上の研磨能率を有していることがわかる.これらの研磨能率のバラツキは, 研 磨回数が 5 回目までが顕著であり, それ以降は比較的安定している。このことから, 研磨パッド表面の状態が研 磨能率のバラツキの原因であると考えられ，それぞれの研磨パッドに適したコンディショニング条件を見出すこ とによりバラツキが抑制できると考えられる．5 時間の研磨実験の後, 研磨パッドの厚さを測定し算出した摩耗 率を図 5 に併せて示す．いずれの研磨パッドでも摩耗率は $1 \mu \mathrm{m} / \mathrm{h}$ 程度であり, ウレタンパッドとエポキシパッド の摩耗量の差は小さいことがわかった。一般的にエポキシ樹脂はウレタン樹脂などの弾性体と比較して硬脆材料 であることが知られているが，本研究で作製したエポキシ研磨パッドは摩耗量が小さく，従来のウレタンパッド と同様の条件において使用が可能であることが確認された。このことから，エポキシパッドのセルフドレス性は ウレタンパッドと同程度であり, これが高研磨能率の要因ではないと判断された.

また, スラリーに対する分散剤の添加が研磨特性に与える影響を評価した. 酸化セリウム砥粒は比重が $6.8 \mathrm{~g} / \mathrm{cm}^{3}$ と大きいことから，水への分散性が悪く擋挥を行わなければただちに沈殿が生じる．そのため，研磨の現場にお いては，スラリーに対し分散剤を添加して使用される。砥粒はこれまで使用した酸化セリウム砥粒に対し分散剤 処理を施したもの（昭和電工(侏製，SHOROX A-10 KT）を用いた。 その他の研磨条件は表 2 と同様である. 図 6 に示寸ように, ウレタンパッドを用いた場合, 分散剤の添加により砥粒が滑りやすくなり, 砥粒の保持力が低下 するため研磨能率がわずかに減少した。 それに対し，エポキシパッドを用いた際には，分散剂を添加しても砥粒 
Table 3 Properties of abrasives

\begin{tabular}{|c|c|c|}
\hline Abrasives & $\begin{array}{c}\text { Mean diameter } \\
(\mu \mathrm{m})\end{array}$ & $\begin{array}{c}\text { Product name, } \\
\text { company }\end{array}$ \\
\hline $\mathrm{SiO}_{2}$ & 0.5 & $\begin{array}{c}\text { SO-C2, } \\
\text { Admatechs Co., Ltd. }\end{array}$ \\
\hline $\mathrm{Fe}_{2} \mathrm{O}_{3}$ & 0.5 & $\begin{array}{c}\text { FE-227101, } \\
\text { Nilaco Corporation }\end{array}$ \\
\hline $\mathrm{Mn}_{2} \mathrm{O}_{3}$ & 1.1 & $\begin{array}{c}\text { 020-47425, } \\
\text { Kishida chemical Co., Ltd. }\end{array}$ \\
\hline $\mathrm{ZrO}_{2}$ & 1.3 & $\begin{array}{c}\text { ZIROX, K-BC0007, } \\
\text { Universal Photonics, Inc. }\end{array}$ \\
\hline $\mathrm{CeO}_{2}$ & 1.2 & $\begin{array}{c}\text { SHOROX A-10, } \\
\text { Showa Denko K.K. }\end{array}$ \\
\hline
\end{tabular}

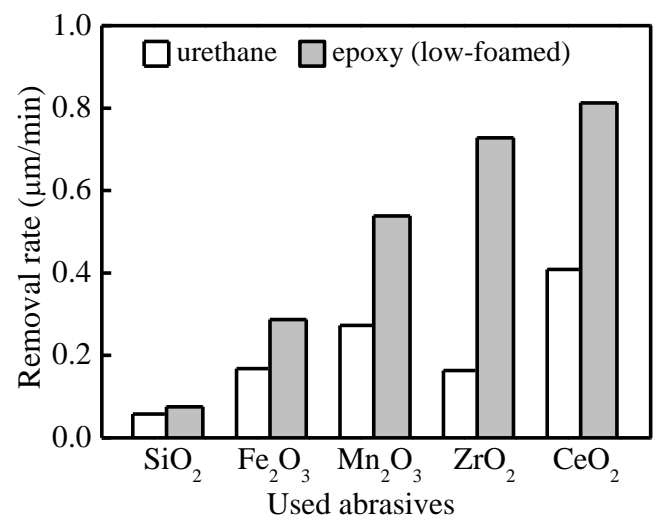

Fig. 10 Comparison of removal rates using various abrasives
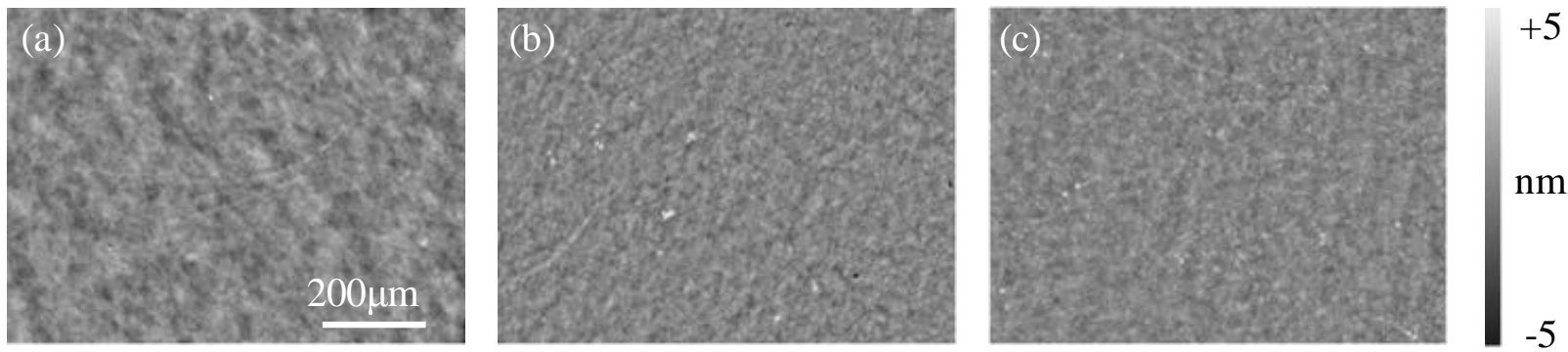

Fig. 11 Optical interferometer images of glass surfaces polished using (a) $\mathrm{CeO}_{2}$ with urethane pad (Ra:0.676nm), (b) $\mathrm{CeO}_{2}$ with epoxy pad (Ra:0.609nm) and (c) $\mathrm{ZrO}_{2}$ with epoxy pad ( $\mathrm{Ra}: 0.62 \mathrm{~nm}$ )

の保持力が維持されたと考えられ, 分散剤無添加の砥粒と同等以上の研磨能率が得られることが明らかとなった. このことは，エポキシパッドが実際の生産現場においても，適用可能であることを示唆する結果である.

\section{$3 \cdot 2$ 研磨後工作物表面の評価}

開発した研磨パッドにより研磨を行ったガラス工作物表面の評価を行った．位相シフト干渉顕微鏡により 0.91 $\times 0.68 \mu \mathrm{m}^{2}$ の領域を評価した表面粗さを図 4 に示寸. 硬度 77 のエポキシパッドで研磨したガラスは $0.7 \mathrm{~nm} \mathrm{Ra}$ 程 度の粗さであり，市販ウレタンパッドと遜色ない表面粗さが得られることがわかった．また研磨後ガラス表面の 形状に関する空間周波数（Power spectral density; PSD）解析 ${ }^{(6)}$ を実施した. PSD 解析は特定の空間周波数での振幅 強度に関連するパラメータで表面を解析するものであり, 空間周波数帯ごとの粗さを考慮した解析である. 図 7 に研磨後ガラス表面を位相シフト干渉顕微鏡により測定したデータを元に，PSD 解析を行った結果を示す．測定 した空間波長である数 $\mu \mathrm{m}$ から $100 \mu \mathrm{m}$ 程度の全領域において, パッドの密度に関わらずウレタンパッドよりエポ キシパッドで研磨したガラス表面の方がパワースペクトル密度が小さく, エポキシパッドにより高い形状精度が 得られることがわかった. エポキシパッドはウレタンパッドと比較して剛性が高いため, 数十 $\mu \mathrm{m}$ の長空間波長 領域において差が顕著に現れていることが確認された. 図 8 に示寸各研磨パッドで研磨したガラス表面の位相シ フト干渉顕微鏡像からも明らかなように， ウレタンパッドで研磨した表面はうねり成分が大きい (Wa : $3.841 \mathrm{~nm})$ のに対し，エポキシパッドで研磨した表面はう衫り成分が小さい（Wa：2nm 以下）ことが確認された.

さらに, 研磨後ガラス表面のふち形状の評価を行った。一般的に, 研磨加工後の工作物は, 工作物の周辺部に 応力が集中し選択的に加工されるため，縁部が丸みをおびた形状（縁ダレ）となる．この縁ダレが大きいと最終 製品として利用できる領域が小さくなるため, 縁ダレを抑制する必要がある. 図 9 にそれぞれの研磨パッドで研 磨したガラスの縁形状を示寸．ウレタンパッドで研磨したガラスは， $1.5 \mu \mathrm{m}$ 程度の縁ダレが生じていることがわ かる，それに対し，低気孔率のエポキシパッドで研磨したガラスの縁ダレは $0.5 \mu \mathrm{m}$ 程度と小さいことがわかる. エポキシパッドの気孔率の増加に伴い，縁ダレは大きくなるもののウレタンパッドと比較して縁ダレの小さい工 作物が得られた。これは, 使用したエポキシパッドの硬度が高いため, 工作物のパッドに対寸る沈みこみが小さ く, 縁への応力集中が小さくなったためであると考えられる. 


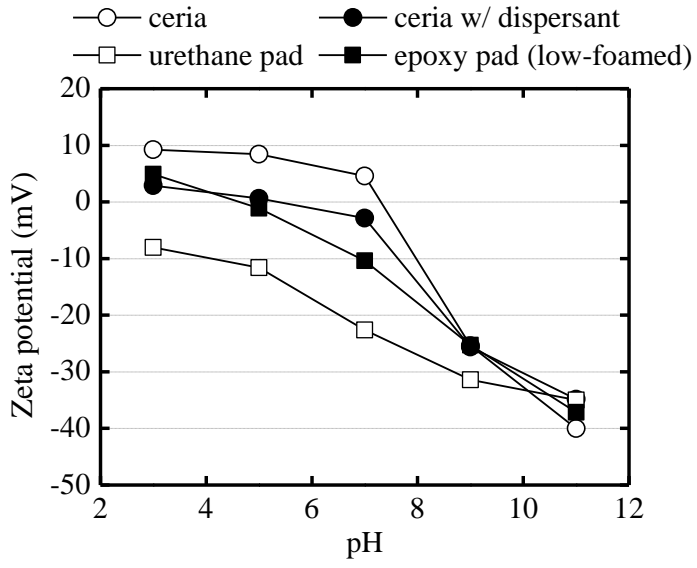

Fig. 12 Zeta potential of ceria abrasives and polishing pads as a function of $\mathrm{pH}$

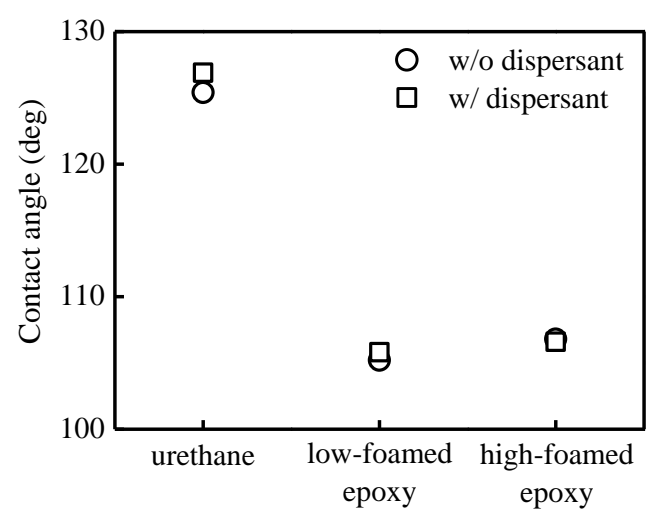

Fig. 13 Contact angles of polishing pads

以上のように，エポキシパッドで研磨したガラス表面は，ウレタンパッドと比較して粗さは同程度であり，う ねりやふち形状の点で大きな優位性を有しており，仕上げ用研磨パッドとしての利用が期待できる.

\section{4. 酸化セリウム代替砥粒の検討}

これまでに述べたように，酸化セリウムを用いた研磨特性評価の結果から，エポキシパッドが従来のウレタン パッドと比較して高い研磨特性を有することが明らかとなった。そこで酸化セリウム以外の砥粒でもエポキシパ ッドを利用した際に，研磨能率が向上することが期待される．エポキシパッドと代替砥粒の組み合わせにより， ウレタンパッドと酸化セリウムを用いた従来研磨と同等以上の研磨能率が達成できれば，酸化セリウムを完全に 代替寸ることが可能である.そこで, 各種酸化物砥粒とエポキシパッドを用いてガラスの研磨特性の評価を行い, 酸化セリウムに代わる代替砥粒の検討を行った．表 3 に使用した酸化物砥粒の種類と粒径を示寸．シリカや酸化 鉄, 酸化ジルコニウムなどの研磨に使用される砥粒を用いた．各砥粒の粒径はおおむね $1 \mu \mathrm{m}$ 前後である. 研磨実 験は，ウレタンパッドおよびエポキシパッドを用いて，各砥粒において同条件で実験を実施した．各砥粒のスラ リー濃度は 3.0wt\%で統一した．その他の実験条件は表 2 に示すものと同様である. 図 10 に各種砥粒のガラスに 対する研磨能率を示すそそれぞれの砥粒において，ウレタンパッドよりもエポキシパッドを用いた場合におおむ 永 2 倍程度の研磨能率が得られることがわかる。特に，市販の酸化ジルコニウム砥粒（ユニバーサルフォトニク ス社製，ZIROX，K-BC0007）を用いた場合，ウレタンパッドと比較してエポキシパッド使用時に約 4 倍の研磨能 率が得られた。 またウレタンパッドと酸化セリウム砥粒を使用した従来研磨に比べて, 研磨能率が 7 割程度向上 する結果が得られた．図 11 （c）に酸化ジルコニウム砥粒とエポキシパッドを用いて研磨したガラス表面の干渉 顕微鏡像を示す．表面にはスクラッチも存在せず，表面粗さは $0.629 \mathrm{~nm} R \mathrm{a}$ であった．これは，ウレタンパッドと 酸化セリウム砥粒の組み合わせ（図 11（a)）やエポキシパットと酸化セリウム砥粒の組み合わせ（図 11（b)）に より研磨した表面と遜色ない值であることが確認された．エポキシパッドの製造時間や材料のコストは，従来の ウレタンパッドとほぼ同程度であり, また酸化ジルコニウム砥粒の価格も酸化セリウム砥粒より安価 (2010 年 12 月現在）である。これらを考慮すると，エポキシパッドを使用することにより仕上げ面品質を維持しながら，酸 化セリウム砥粒を酸化ジルコニウム砥粒に完全に代替することが可能であると判断される.

\section{5. 高研磨能率の原因究明}

これまでに述べたように，開発したエポキシパッドは従来のウレタンパッドと比較して高い研磨特性を有して いることが明らかとなった. また, 酸化ジルコニウム砥粒とエポキシパッドを利用することにより, 従来研磨 (酸 化セリウム砥粒とウレタンパッド）の研磨能率を上回ることが確認され，酸化セリウムの代替砥粒としての可能 性が確認された，本章では研磨パッドの表面ゼータ電位や接触角，動摩擦係数などの材料特性を評価し，エポキ シパッドで高い研磨能率が得られる要因について考察を行った。 


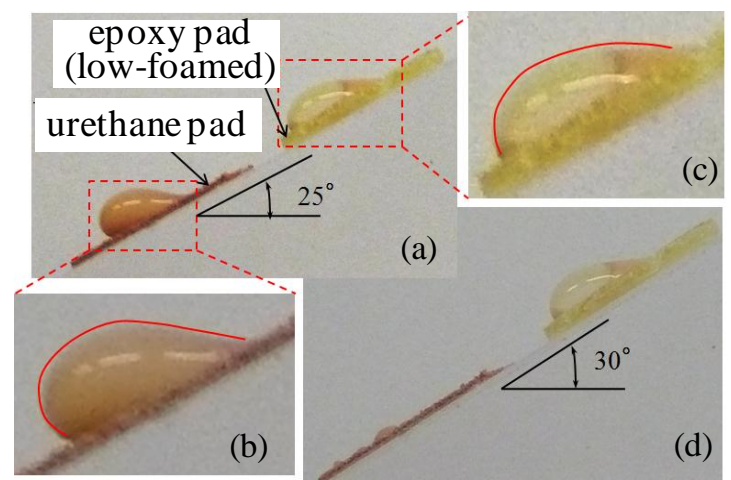

Fig. 14 Result of inclination test of polishing pads with $\mathrm{CeO}_{2}$ slurry

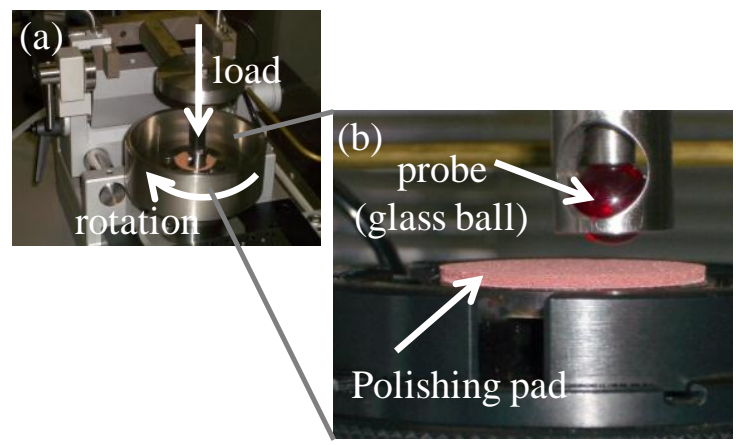

Fig. 16 Experimental apparatus for measuring the dynamic friction coefficient of polishing pads. (a) overall view, (b) detail view of measurement area

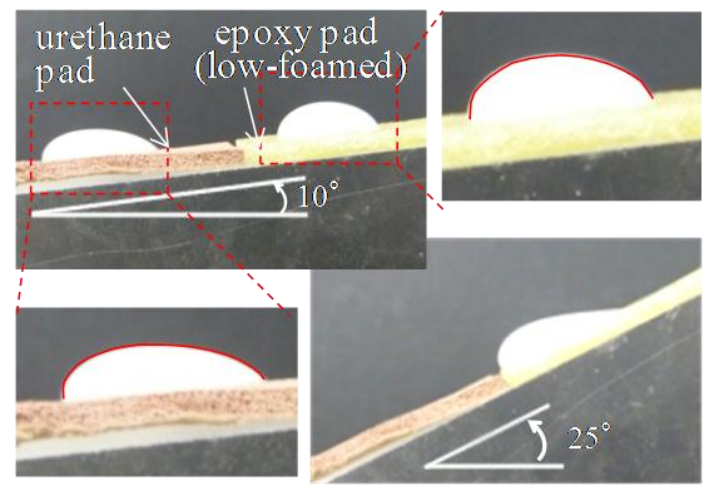

Fig. 15 Result of inclination test of polishing pads with $\mathrm{ZrO}_{2}$ slurry.

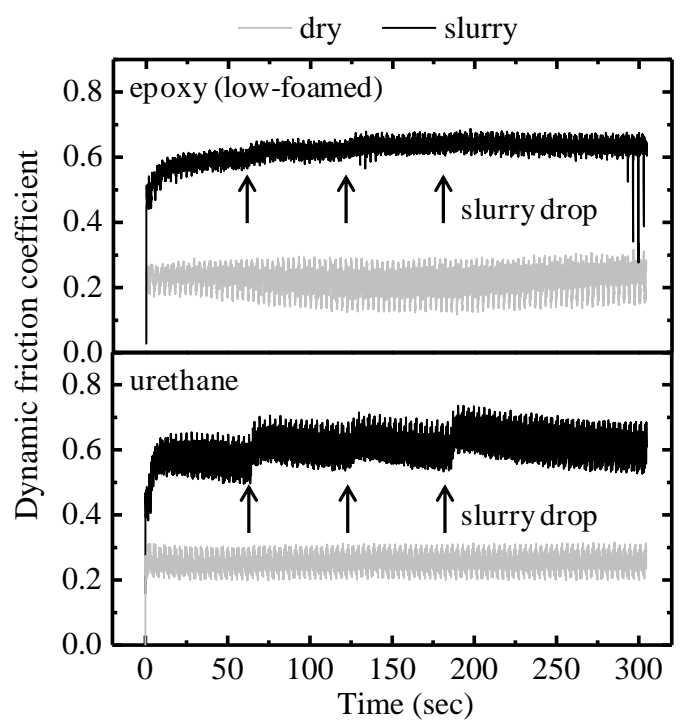

Fig. 17 Dynamic friction coefficient of polishing pad surfaces as a function of time

\section{$5 \cdot 1 \quad$ 研磨パッド表面のゼータ電位の評価}

研磨パッド表面および酸化セリウム砥粒をゼータ電位計（大塚電子(侏製，ELSZ-2R）により評価した。測定は 常温の純水中で行った. また, 測定溶液の $\mathrm{pH}$ を $0.1 \mathrm{~mol} / \mathrm{L}$ の塩酸および水酸化カリウム水溶液で変化させ, 各 $\mathrm{pH}$ におけるゼータ電位を評価した．図 12 に各試料のゼータ電位と $\mathrm{pH}$ の関係を示す. 分散剂が添加されていない酸 化セリウムスラリーの $\mathrm{pH}$ は 7 であり，この $\mathrm{pH}$ における酸化セリウム砥粒のゼータ電位は+4.55mV と正の值を 示した. 同じ $\mathrm{pH}$ では, ウレタンパッドが-22.6mV, エポキシパッドが-10.4mVであり共に負の電位值を示したが, ウレタンパッドの方が絶対值が大きいことがわかった。つまり， ウレタンパッドの方がパッド表面と砥粒間の引 力が大きいことを示している. それに対し, 分散剤を添加した酸化セリウムスラリーの $\mathrm{pH}$ はおよそ10であった. この $\mathrm{pH}$ においては, ウレタンパッドおよびエポキシパッド共に- $35 \mathrm{mV}$ 程度のゼータ電位であり, 二つのパッド で大きな差異は認められなかった．しかし，第 3 章で述べたように，分散剤を添加した酸化セリウム砥粒を使用 した場合においても，エポキシパッドはウレタンパッドよりも2 倍以上の研磨能率が得られている. 研磨パッド 表面のゼー夕電位は $\mathrm{pH}$ が 7 において差があったものの, $\mathrm{pH}$ が 10 では差がなく, これらの結果から判断すると, パッド表面のゼータ電位の違いが高い研磨能率の支配要因ではないと結論づけられる.

\section{$5 \cdot 2$ スラリーの滞留性の評価}

スラリーの滞留性に関して確認を行うため, 研磨パッド表面の接触角およびスラリーの滑落に関する評価を行 った。接触角の測定は, 研磨パッド表面をフェイシングおよびドレッシングした後, 接触角計（協和界面科学(㑣) 
製，CA-DT）を用いて行った．図 13 に各研磨パッド表面の水に対する接触角を示す．ウレタンパッドと比較す ると, 気孔率に関わらずエポキシパッドの接触角が小さく, 親水性が高いことがわかる. また, 分散剂を添加し た砥粒を用いても，接触角の変化は小さかった．次に，酸化セリウムスラリーを $60 \mu \mathrm{L}$ 滴下した研磨パッドを傾 斜させてスラリーの流動を観察した様子を図 14 に示す。傾斜角 25 度ではスラリーは流れ落ちず（図 14 (a)), 研磨パッド上にとどまっていたが，ウレタンパッドの場合は液滴が下に大きくせり出した状態（図 $14(\mathrm{~b})$ ) とな った．傾斜角を 30 度にしたところ，ウレタンパッド上の液滴は滑落してしまった，一方，エポキシパッド上の夜 滴は傾斜角を 55 度にしても滑落しないことが確認できた. また分散剂添加スラリーにおいてもほぼ同様の傾向が 確認された．以上の評価の結果，エポキシパッドはウレタンパッドと比較して酸化セリウムスラリーに対する親 和性が高く，高いスラリー保持力を有することが確認された．同様の傾向は酸化ジルコニウムスラリーを用いた 試験でも確認された. 図 15 に示すように酸化ジルコニウムスラリーの場合でも, やはりエポキシパッドがウレタ ンパッドに比べ大きな滑落角を持つことがわかった. ウレタンパッド上ではおよそ 25 度の傾斜角でスラリーが滑 落したのに対し, エポキシパッド上での滑落角はおよそ 40 度であった. このように酸化ジルコニウムスラリーの 滑落角は酸化セリウムスラリーよりも小さいことがわかった，それぞれのパッドとスラリーの組み合わせにおけ る滑落角を小さい順から並べると，研磨能率の順と同じであり正の相関が認められた．このことから，滑落角が 大きい，つまり砥粒の保持力が高いことがエポキシパッドで高い研磨能率が得られた要因であると言える.

\section{$5 \cdot 3$ 研磨パッド表面の動摩擦係数の評価}

次に研磨能率と比較的相関関係が強いと言われている(7)研磨パッド表面の動摩擦係数の評価を行った. 摩擦係 数の計測は図 16 に示すトライボ試験機（Center for tribology 社, UMT-2M）を用い，ボールオンディスク方式（JIS R1613-1993）により試験を行った．各研磨パッドの表面は実際の研磨実験を再現するため, 測定前にフェイシン グおよびドレッシングを施しており, 乾式状態および酸化セリウムスラリーを滴下した湿式状態で計測を行った. 研磨パッドの回転速度は $10 \mathrm{~mm} / \mathrm{s}$ であり, ガラスボール（直径 $5 \mathrm{~mm} ）$ のパッドに対する接触荷重は $200 \mathrm{~g}$ とした. 湿式状態の試験は，研磨パッドをスラリー中に 24 時間浸漬させたのち，測定直前にスラリーを $1 \mathrm{~mL}$ 滴下し，そ の後 1 分毎に $1 \mathrm{~mL}$ ずつ 3 分までスラリーを滴下しながら実施した. 図 17 にそれぞれの研磨パッドの動摩擦係数 と時間の関係を示す. 二つの研磨パッドで共通して, 乾式状態と比較して湿式状態では摩擦係数が高くなってい ることがわかる. スラリー中において, ウレタンパッドの摩擦係数はスラリー滴下後, 時間と共に低下し, 再び スラリーを滴下寸ると高くなる傾向が確認された。 これは, ウレタンパッド上ではスラリーがすぐに排出され滞 留性が悪いことを示している，それに対し，エポキシパッドの摩擦係数はほぼ一定の值を維持していることがわ かった.この傾向は，エポキシパッドの気孔率に関わらず確認された。これは，スラリーの滞留性がよくパッド 表面上に保持されていることを示唆する結果である.

以上の結果を統合すると，エポキシパッドはウレタンパッドと比較してスラリーの保持力が高く，工作物表面 により多くの砥粒が作用すると考察される，そのため， ウレタンパッドと比較してエポキシパッドにより高い研 磨能率が得られたと結論づけられる。

\section{6. 結 論}

本研究では, ガラスの精密研磨用途として, エポキシ樹脂研磨パッドの開発を行った. 研磨特性の評価を行い, 従来のウレタン研磨パッドと比較した。 また, 酸化セリウムを代替する砥粒に関する検討を行った他, 高い研磨 能率が得られる要因について調査を行った，以下に，本研究で得られた結果をまとめる.

（1）樹脂に配合する発泡剂の割合を変化させることによりエポキシパッドの物性值を変化させることが可能 であり，発泡剤の添加量を増加させるとパッドの硬度が低下寸ることがわかった.

（2）作製したエポキシパッドを用い，ガラスの研磨特性の評価を行った．その結果，市販のウレタンパッド と比較して，2 倍程度の高い研磨能率が得られた他，高い幾何学的精度が得られることがわかった。

（3）酸化セリウム代替砥粒の評価を行った。いずれの砥粒を使用してもエポキシパッド使用時に研磨能率の 向上が確認された. 特に酸化ジルコニウム砥粒とエポキシパッドの組み合わせの研磨能率が高く, 酸化 セリウムを代替する可能性が見出された. 
（4）エポキシパッドの高研磨能率の要因について考察した. 接触角や滑落角の評価, 動摩擦係数の評価の結 果, エポキシパッドはスラリーの保持力が高く，これが高研磨能率の要因であることがわかった.

\section{謝 辞}

本研究の一部は，経済産業省/NEDO（新エネルギー・産業技術総合開発機構）希少金属代替材料開発プロジェ クト「精密研磨向けセリウム使用量低減技術開発及び代替材料開発」の援助を受けて行われました．ここに深く 謝意を表します。

\section{文献}

(1) 村田順二, 張 宇, 谷 泰弘, “多孔質エポキシ樹脂研磨パッドの最適化に関する研究”, 2010 年度砥粒加工学会 学術講演会講演論文集, pp. 105-106.

（2）エポキシ樹脂技術協会編，総説 エポキシ樹脂，第一巻 (2003)，p.16，エポキシ樹脂技術協会.

(3) 岡田昭次郎, “研削砥石の結合剂としてのエポキシ樹脂の応用”，高分子論文集，vol. 32 , No. 3 (1975), pp. 142-146.

(4) 男澤麻子, 河田研治, 榎本俊之, 谷 泰弘, 鈴木真里, 盧, 毅申, “複合粒子研磨法の開発 一樹脂工具プレートに 関する検討一”, 砥粒加工学会誌 vol. 48, No. 9 (2004), pp 495-499.

（5）土肥俊郎，黒河周平，大西 修，山崎 努，“超精密研磨/CMP 技術とその最新動向（その2）-最新の CMP 技術と トライボケミカル応用-”トロイボロジスト，vol. 55， No.11(2010)， pp. 809-813.

（6）角田均, “シリコンウエハー表面マイクロラフネスの評価一パワースペクトル解析の応用一”, 応用物理, vol. 12, No. 12 (1997), pp. 1316-1319.

（7）朴栽弘, 羽場真一, 木下正治, 丁海島, “各種研磨パッドの摩擦特性による CMP の研究”, 2004 年度精密工学会 春季大会学術講演会講演論文集, pp. 955-956. 